ISSN [E]: 2477-0515 ISSN [P]: 2339-0794

DOI: 10.26858/jnp.v9i1.20404

Online: https://ojs.unm.ac.id/nalar

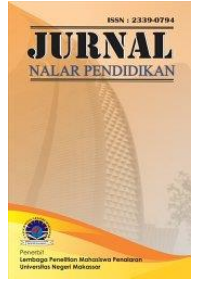

\title{
MOTIVASI SISWA SD MENGIKUTI BIMBINGAN BELAJAR OMAH SINAU
}

\section{BLORA}

\author{
Titania Mega Angayomi' ${ }^{1}$, Irfai Fathurohman², M Syaffruddin Kuryanto ${ }^{3}$ \\ 1,2,3, Program Studi Guru Sekolah Dasar, Fakultas Keguruan dan Ilmu Pendidikan, Universitas Muria \\ Kudus \\ megaangayomi@gmail.com ${ }^{1}$
}

\begin{abstract}
Abstrak
Penelitian ini bertujuan untuk menganalisis motivasi siswa yang mengikuti bimbingan belajar Omah Sinau. Penelitian ini merupakan penelitian kualitatif yang dilaksanakan di Desa Jejeruk Kecamatan Blora Kabupaten Blora. Subjek penelitian ini yaitu 3 siswa dengan hasil belajar rendah dan 3 siswa dengan hasil belajar tinggi, orang tua siswa yang dikategorikan berdasarkan latar belakang pendidikan dan pekerjaan, dan tutor. Teknik pengumpulan data yang digunakan meliputi observasi, wawancara, dan dokumentasi penelitian. Wawancara dilaksanakan dengan siswa, tutor, dan orang tua. Analisis data menggunakan model Milles and Huberman yakni analisis dilakukan meliputi pengumpulan data, reduksi data, penyajian data dan penarikan kesimpulan. Hasil penelitian menunjukkan bahwa (1) siswa dengan hasil belajar rendah dan hasil belajar tinggi sama-sama memiliki motivasi instrinsik dan motivasi ekstrinsik, tetapi yang membedakan yaitu faktor internal dari dalam diri siswa. (2) pekerjaan orang tua tidak mempengaruhi siswa dalam meningkatkan motivasi belajar. Karena orang tua pekerja dan ibu rumah tangga memiliki andil yang sama dalam mengikut sertakan siswa mengikuti bimbingan belajar. (3) Latar belakang pendidikan orang tua tidak menjadi penghalang untuk membantu siswa meningkatkan motivasi belajar. Karena keterbatasan pengetahuan orang tua untuk mengimbangi tingkat belajar siswa.
\end{abstract}

Kata kunci: Motivasi belajar, Bimbingan Belajar, Faktor penyebab.

\section{MOTIVATION OF PRIMARY SCHOOL STUDENTS IN JOIN THE LEARNING COURSE OF OMAH SINAU BLORA}

\begin{abstract}
This study aims to analyze the motivation of students who follow Omah Sinau's tutoring. This research is a qualitative research conducted in Jejeruk Village, Blora District, Blora Regency. The research subjects were 3 students with low learning outcomes and 3 students with high learning outcomes, parents of students who were categorized based on educational and occupational backgrounds, and tutors. Data collection techniques used include observation, interviews, and research documentation. Interviews were conducted with students, tutors, and parents. Data analysis used the Milles and Huberman model, the analysis was carried out including data collection, data reduction, data presentation and conclusion drawing, the results showed that (1) students with low learning outcomes and high learning outcomes both had intrinsic motivation and extrinsic motivation, but the difference is internal factors from within students. (2) the work of parents does not affect students in increasing learning motivation. Because working parents and housewives have an equal share in enrolling students in tutoring. (3) The educational background of parents is not a barrier to help students increase their motivation to learn. Due to the limited knowledge of parents to compensate for the level of student learning.
\end{abstract}

Keywords: learning motivation, learning course, causative factors.

PENDAHULUAN

Pada zaman sekarang dunia pendidikan mengalami perkembangan cukup pesat dari tahun ke tahun yang akan memunculkan fenomena baru salah satu aspeknya adalah hadirnya berbagai bimbingan belajar di kota-kota, bahkan sampai ke desa-desa. 
Fenomena maraknya bimbingan belajar ini disambut dari antusias dari siswa yang ikut bimbingan belajar khususnya pada siswa Sekolah Dasar. Bimbingan belajar mengalami peningkatan jumlah peserta karena siswa mengalami masalah belajar di sekolah formal untuk membantunya mengatasi, atau siswa membutuhkan belajar tambah untuk meningkatkan prestasi belajarnya yang di sekolah. Hal ini yang mendorong siswa untuk mengikuti bimbingan belajar

Berdasarkan hasil observasi, peneliti menemukan permasalahan siswa yang belajar di bimbingan belajar Omah Sinau yang mengaku lebih suka belajar di bimbingan belajar dari pada belajar di rumah. Siswa juga mengaku merasa malas dan tidak bersemangat saat diminta oleh orang tua siswa untuk belajar. Pada dasarnya siswa yang belajar di Bimbingan belajar Omah Sinau mengakui bahwa saat diperintah oleh orang tua untuk belajar yang terjadi yaitu mengabaikan, menunda, dan akhirnya tidak jadi untuk belajar.

Siswa mengakui bahwa jika dirumah lebih banyak bermain handphone, menonton televisi, dan bermain. Berbeda ketika mengikuti bimbingan belajar, siswa menunjukkan antusias dan semangat selama mengikuti proses bimbingan belajar. Siswa tampak tidak terlihat malas selama ikut kegiatan bimbingan belajar. Siswa bersungguh-sungguh seperti belajar di sekolah formal dengan patuh mendengarkan dan memperhatikan penjelasan yang diberikan oleh tutor. Saat waktu belajar telah berakhir siswa terlihat masih tetap ingin untuk belajar dan mengeluh waktu belajar terlalu singkat.

Berdasarkan permasalahan tersebut peneliti bermaksud melakukan penelitian mengenai motivasi belajar siswa SD mengikuti bimbingan belajar Omah Sinau Blora. Belajar merupakan suatu aktivitas yang dilakukan dalam pencapaian tujuan. Untuk mencapai tujuan perlu adanya motivasi. Motivasi adalah serangkaian usaha individu yang ingin melakukan suatu hal agar tujuan yang diharapkan tercapai. Motivasi dapat dirangsang oleh faktor eksternal. Faktor lingkungan dapat menjadi faktor motivasi dari luar diri seseorang. Lingkungan ini berupa keluarga, teman, dan masyarakat.

Bimbingan belajar merupakan suatu wadah yang diperuntukkan dalam membantu siswa untuk memperdalam materi pelajaran di sekolah [1]. Bimbel bertujuan bagi siswa yang membutuhkan materi pelajaran tambahan selain di sekolah. Materi pelajaran yang diberikan oleh bimbel sama dengan materi yang ada di sekolah. Bimbel sangat tepat terhadap siswa yang butuh waktu selain di luar sekolah formal. Susanto dalam Referensi [2] mengemukakan bimbingan belajar merupakan keberhasilan terhadap pembiasaan bidang akademis secara maksimal berdasarkan kemampuan internal siswa. Bimbingan belajar adalah tempat belajar yang ada di luar sekolah formal yang memberikan bantuan kepada anak dalam mengatasi masalah belajar sehingga mampu belajar dengan tepat dan mampu mencapai tujuan belajar yang diharapkan. Bimbingan belajar mengutamakan pendampingan kepada siswa melalui tutor agar siswa merasakan kenyamanan dan mau kegiatan belajar sesuai tujuan belajar yang ingin dicapai. Tujuan dari bimbingan yakni sebagai bentuk pengembangan seluruh potensi yang dimiliki siswa secara optimal terhadap mencegah timbulnya dalam menyelesaikan masalah belajar siswa.

Bimbingan belajar memberikan layanan belajar untuk siswa terhadap penyesuaian masalah belajar yang dialami oleh siswa. Melalui pengamatan spesifikasi masalah yang dihadapi siswa, tutor akan merumuskan program layanan belajar untuk siswa. Motivasi siswa mengikuti bimbingan belajar bisa timbul dengan adanya layanan yang diberikan oleh tutor atau pembimbing. Sebagaimana dikemukakan oleh Siswanto dalam Referensi [3] peran dari guru, instruktur, pelatih, serta tutor untuk membimbing atau menunjukkan cara agar tujuan pembelajaran dapat tercapai.

Tutor adalah pendidik yang berada di luar sekolah formal yang memberikan bantuan kepada siswa dalam mengatasi masalah dan hambatan belajar yang siswa hadapi. Tutor sebagai pendidik diluar sekolah formal memiliki peran yang sama seperti pendidikan di sekolah formal yang memberikan wadah untuk siswa untuk mengatasi hambatan belajar yang ada. Besarnya antusias dari siswa dibuktikan melalui harapan siswa kepada tutor bimbingan belajar dalam membantu masalah belajar yang dihadapi dengan belajar di bimbingan belajar.

Permasalahan yang kerap terjadi pada siswa dikarenakan perhatian karena kurangnya perhatian orang tua ketika berada di rumah. Selain hal tersebut siswa merasa kurang puas dengan apa yang disampaikan oleh orang tua, jika dia mengalami kesulitan belajar. Karena jika di rumah siswa akan langsung diberi tahu jawabannya tanpa dijelaskan bagaimana cara penyelesaiannya. Oleh karena itu siswa lebih suka belajar di bimbingan belajar sebab adanya peran tutor dalam proses belajar untuk memahami materi sehingga siswa menjadi lebih tertarik dan puas belajar di bimbingan belajar sesuai tujuan yang akan dicapai..

Adanya pernyataan tersebut didukung dengan temuan penelitian dari Khoerunnisa \& Grafiyana dalam Referensi [4] mengemukakan bahwa secara garis besar, motivasi siswa lebih membantu memahami materi pembelajaran dalam mengikuti bimbingan belajar. Motivasi adalah hal yang paling penting agar mampu mencapai segala tujuan yang ingin dicapai. Masalah belajar yang dihadapi siswa mampu teratasi baik karena adanya motivasi yang berasal dari dorongan dalam diri maupun dukungan dari luar siswa. 
Selain itu menurut penelitian dari Alwan \& Hendri pada Referensi [5] bahwa faktor keluarga menjadi penyebab tidak optimalnya siswa belajar dengan baik, kurangnya waktu belajar, serta adanya faktor dari orang tua. keluarga adalah pencipta suasana pertama belajar sebelum belajar di sekolah maupun di bimbel. Jadi orang tua yang memberikan dukungan atau dorongan yang baik bagi anakanya walaupun anak tersebut memiliki masalah belajar ataupun anak yang berprestasi maka anak tersebut akan memilik kemaua untuk belajar. Tetapi jika orang tua kurang perhatian dan tidak memberikan dukungan kepada anak dalam hal belajar, maka anak akan menjadi tidak ada kemauan untuk belajar.

Motivasi berperan sangat penting terhadap siswa karena memberi dampak serius dalam bersikap dan berperilaku. Sebab itu Siswa yang mempunyai motivasi pasti mempunyai minat dalam aktivitas belajar dan berusaha lebih optimal dibanding siswa yang kurang berminat. Sejalan dengan pendapat Slameto dalam Referensi [6] bahwa setiap kegiatan yang seseorang minati perlu diperhatikan secara terus-menurus dan disertai melalui rasa senang untuk memperoleh rasa kepuasan. Sependapat dengan Black \& Allen dalam Referensi [7] nilai akademik yang baik dan tingkat pemahaman yang tinggi serta kebiasaan belajar yang tersistematis merupakan bentuk dari minat dan mtivasi belajar yang tinggi.

Ciri-ciri siswa memiliki motivasi ditandai dengan adanya ketertarikan untuk belajar dengan senang hati, berpartisipasi dan lebih aktif, serta sikap perhatian penuh [8]. Proses pembelajaran akan tercapai apabila siswa memiliki faktor pendorong motivasi untuk belajar. Salah satu faktor yang mempengaruhi motivasi dan minat siswa dalam belajar menurut Syah dalam Referensi [9] ada dua yakni: (1) Faktor internal, faktor yang berasal di dalam diri siswa serta (2) Faktor Eksternal yang berasal diluar diri siswa.

Berdasarkan penjabaran data diatas dapat dirumuskan masalah dalam penelitian ini yakni untuk mengetahui motivasi belajar siswa dalam mengikuti bimbingan belajar Omah Sinau Blora. Kemudian yang menjadi tujuan dalam penelitian ini ialah untuk menganalisis motivasi belajar siswa yang mengikuti bimbingan belajar Omah Sinau Blora.

\section{METODE PENELITIAN}

Jenis penelitian deskriptif kualitatif digunakan dalam penelitian ini dengan memilih lokasi penelitian di Kecamatan Blora, Kabupaten Blora dengan lokasi penelitian di Desa Jejeruk. Subjek penelitian yakni siswa kriteria hasil belajar rendah serta kriteria siswa hasil belajar tinggi yang ada di bimbingan belajar Omah Sinau, teknik dan instrument meliputi observasi, wawancara, dan dokumentasi penelitian terhadap pengumpulan data yang digunakan.

Sumber data dalam penelitian ini diperoleh dari hasil observasi, dokumentasi, dan wawancara dengan informan. Adapun pelaksanaan wawancara dilaksanakan dengan siswa berdasarkan kategori siswa dengan hasil belajar rendah serta kriteria hasil belajar tinggi, orang tua dengan kategori latar belakang Pendidikan dan jenis pekerjaan, dan tutor yang ketiganya merupakan informan utama. Peneliti menggunakan model teknik analisis data dari Referensi [10] yakni analisis dilakukan meliputi pengumpulan data, reduksi data, dan penyajian data, serta kesimpulan. Data dikumpulkan melalui observasi serta dari pelaksanaan wawancara. Tujuan reduksi data untuk mengklasifikasikan data dari temuan peneliti. Adanya penyajian data dilakukan setelah tahap pengumpulan data dan reduksi data. Serta disajikan dalam bentuk deskriptif. Terakhir tahap penarikan kesimpulan setalah semua data terangkum dan disajikan dengan baik sehingga temuan pada penelitian ini dapat bersifat mutakhir serta bersifat objektif.

\section{HASIL DAN PEMBAHASAN}

Analisis motivasi belajar siswa dalam mengikuti bimbingan belajar Omah Sinau Blora terdapat perbedaan. Berdasarkan hasil observasi, wawancara, dan dokumentasi dengan siswa hasil belajar rendah yaitu APH, NDA dan RTMP menunjukkan bahwa siswa dengan hasil belajar rendah disebabkan karena siswa mengalami kendala dalam belajar sehingga, siswa tidak dapat mencapai tujuan belajar yang siswa inginkan. Hasil penelitian dari Darimi dalam Referensi [11] menjelasakan bahwa hambatan belajar siswa jika terus dibiarkan akan berdampak pada tujuan pembelajaran yang tidak optimal. Sehingga kesulitan tersebut dapat diatasi siswa melalui bantuan, baik dalam mencerna bahan materi hingga dalam mengatasi hambatan masalah belajar.

Sejalan dengan hasil penelitian yang sudah dilakukan tujuan orang tua siswa mengikuti bimbingan belajar karena siswa mengalami masalah belajar. Adapun kesulitan belajar siswa ini ada pada pelajaran matematika. Setelah mengikuti bimbingan belajar siswa secara bertahap bisa mengatasi kesulitan belajarnya. Hal tersebut didukung dengan hasil wawancara dan observasi siswa bahwa mereka mengalami peningkatan hasil belajar. Adanya peran tutor di bimbingan belajar mampu membantu siswa dalam menuntaskan kesulitan belajar yang ia alami. 
Hasil wawancara dengan siswa menjelasakan bahwa, siswa lebih suka mengikuti bimbel karena beberapa alasan, diantaranya (1) Memiliki lebih banyak teman, (2) Penyampaian materi oleh tutor mudah dipahami. Didukung dengan penelitian terdahulu dari Eriany, Hernawati, dan Goeritno Referensi [12] bahwa siswa mengikuti bimbingan belajar dipengaruhi oleh faktor ekstrinsik yang berperan adalah orang tua, teman, dan orang lain. Hal ini diperkuat dengan hasil wawancara kepada siswa bahwa keikutsertaannya karena adanya dorongan dari orang tua, teman yang meningkatkan semangat belajarnya, serta peran tutor yang sudah terlaksana.

Selain itu siswa dengan hasil belajar rendah ternyata memiliki minat dalam belajar. Hal observasi menunjukkan bahwa siswa dengan hasil belajar tidak bisa dikatakan bahwa mereka tidak memiliki motivasi belajar. Sejalan dengan hasil penelitian dari Muhajis pada Referensi [13] menunjukkan adanya tingkat motivasi belajar saling berhubungan positif dengan prestasi belajar siswa, namun karena hasil pembahasan menunjukkan hubungan antara motivasi belajar dengan hasil belajar siswa dikatakan lemah karena sebesar $0,10 \%$. Hal ini berarti bahwa jika motivasi belajar meningkat maka terdapat peluang kecenderungan hasil belajar mampu meningkat, begitupun sebaliknya.

Sejalan dengan hasil observasi bahwa siswa dengan hasil belajar rendah diukur dengan 5 indikator motivasi belajar dari Aritonang pada Referensi [14] yang tercapai yakni: (1) Mandiri ketika belajar, (2) Mampu menghadapi masalah, (3) Belajar dengan tekun. Maka motivasi belajar siswa dengan hasil belajar rendah termasuk kedalam motivasi ekstrinsik maupun intrinsik. Kedua motivasi ini sama-sama dimiliki oleh siswa, sedangkan siswa yang memperoleh hasil belajar tinggi mempunyai keinginan besar dalam belajar. Sejalan dengan Warti dalam Referensi [15] menjelaskan bahwa tingkat keberhasilan siswa dalam belajar di tandai dengan hasil belajar yang memuaskan. Hasil wawancara tutor menjelaskan bahwa siswa yang memperoleh hasil belajar tinggi yaitu siswa ALP DSYS, dan YAS memiliki keinginan belajar yang besar. Hal tersebut ditandai dengan aktifnya siswa dalam bertanya atau berpendapat, serta memiliki nilai belajar yang baik disetiap pertemuan.

Faktor internal bagi siswa memperoleh hasil belajar tinggi sangat terlihat dibanding siswa yang memperoleh hasil belajar rendah. Hal ini terbukti berdasarkan hasil wawancara bersama siswa ALP dan DSYS menjelaskan bahwa siswa memiliki keinginan sendiri untuk mengikuti bimbel dan lebih menyukai belajar di bimbel daripada di rumah. Sedangkan hasil wawancara dengan orang tua siswa hasil belajar tinggi menjelaskan bahwa orang tua siswa juga meminta untuk mengikuti bimbel. Sedangkan YAS mendapatkan dorongan orang tua agar mengikuti bimbingan belajar, karena sebelumnya belum ada keinginan untuk mengikuti bimbel. Walaupun dari dorongan orang tua, YAS sudah menunjukkan motivasi belajar yang tinggi selama mengikuti bimbel. Hal ini dijelaskan oleh YAS bahwa dia lebih suka belajar di di bimbel karena jika belajar di rumah lebih banyak dimarahi.

Sejalan dengan hasil penelitian dari Eriany, Hernawati, dan Goeritno dalam Referensi [12] bahwa faktor instrinsik di dalam diri siswa mempengaruhi siswa SMP yang mengikuti bimbel sehingga dibutuhkan rasa yang sangat besar. Begitu juga dengan siswa ALP, DSYS, dan YAS dengan hasil belajar tinggi di bimbel Omah Sinau bahwa hasil Observasi menunjukkan bahwa faktor instrinsik yang ada di dalam dirinya ditunjukkan dengan keaktifan bertanya, dan berpendapat, antusias dan semangat dalam mengikuti pembelajaran, dan juga mampu menguasai materi dan mendapatkan hasil belajar yang tinggi.

Penelitian dari Khoerunnisa \& Grafiyana pada Referensi [4] menjelaskan bahwa siswa yang memiliki motivasi positif mempunyai motivasi positif mempunyai motivasi instrinsik yang baik dan juga motivasi ekstrinsik yang baik juga, hal ini ditandai dengan ketertarikan siswa dalam belajar matematika, ketertarikan dalam penyelesaian permasalahan, siswa yang mengajukan pertanyaan mengenai materi atau permasalahan matematika. Hal tersebut sesuai dengan siswa ALP, DSYS, dan YAS bahwa hasil observasi menunjukkan siswa mencapai semua indikator motivasi belajar yang diukur dengan indikator menurut Aritonang dalam Referensi [14] yakni: 1) Belajar dengan tekun, 2) Kuat memecahkan masalah , 3) Minat serta belajar yang tersistematis, 4) Belajar mandiri, 5) Memiliki prestasi belajar.

Maka motivasi belajar yang dimiliki siswa dengan hasil belajar tinggi termasuk motivasi instrinsik dan motivasi ekstrinsik. Karena siswa memiliki motivasi instrinsik yang baik dan juga memiliki motivasi ekstrinsik yang sama baik.

Berhubungan dengan perolehan data dari peneliti terhadap temuan penelitian maka peneliti menyajikan data yang diperoleh dan dikemukakan dalam bentuk tabel yakni: 
Tabel 1. Analisis Motivasi Belajar Siswa

\begin{tabular}{cccc}
\hline No & Nama & $\begin{array}{c}\text { Hasil } \\
\text { belajar }\end{array}$ & Motivasi Belajar \\
\hline 1. & APH & Rendah & $\begin{array}{c}\text { Motivasi Instrinsik } \\
\text { \& Motivasi } \\
\end{array}$ \\
& & & Ekstrinsik \\
2. & NDA & Rendah & $\begin{array}{c}\text { Motivasi Instrinsik } \\
\text { \& Motivasi }\end{array}$ \\
& & & Ekstrinsik \\
3. & RTMP & Rendah & $\begin{array}{c}\text { Motivasi Instrinsik } \\
\text { \& Motivasi }\end{array}$ \\
& & & Ekstrinsik \\
4. & ALP & Tinggi & Motivasi Instrinsik \\
& & & \& Motivasi \\
& & & Ekstrinsik \\
5. & DSYS & Tinggi & Motivasi Instrinsik \\
& & & \& Motivasi \\
& & & Ekstrinsik \\
6. & YSA & Tinggi & Motivasi Instrinsik \\
& & & \& Motivasi \\
& & & Ekstrinsik \\
\hline
\end{tabular}

Berdasarkan tabel 1 dapat ditarik kesimpulan bahwa perolehan hasil belajar siswa yang rendah dan tinggi memiliki motivasi ekstrinsik dan motivasi instrinsik yang sama baiknya. Hal yang membedakan adalah faktor internal yang menyebabkan siswa memiliki motivasi instrinsik. Motivasi instrinsik siswa yang memperoleh hasil belajar rendah timbul sesudah diberikan dorongan dari orang tua dan peran tutor. Sedangkan siswa yang memperoleh hasil belajar tinggi tentunya memiliki motivasi instrinsik siswa memang sudah ada didalam dirinya tanpa sebelum ada dorongan dari orang tua, dan juga peran dari tutor.

Berdasarkan hasil penelitian yang dikategori menurut latarbelakang pendidikan dan Pekerjaan orang tua, untuk mengetahui adakah kaitnya terhadap motivasi siswa dalam mengikuti bimbingan belajar didapatkan data sebagai berikut:

Tabel 2. Latar belakang Pendidikan dan Pekerjaan orang tua

\begin{tabular}{|c|c|c|c|c|}
\hline No & Nama & $\begin{array}{c}\text { Hasil } \\
\text { Belajar }\end{array}$ & $\begin{array}{c}\text { Pendidik } \\
\text { an Orang } \\
\text { Tua }\end{array}$ & $\begin{array}{c}\text { Pekerja } \\
\text { an } \\
\text { Orang } \\
\text { Tua }\end{array}$ \\
\hline 1. & APH & Rendah & SD & IRT \\
\hline 2. & NDA & Rendah & SD & IRT \\
\hline 3. & $\begin{array}{c}\text { RTM } \\
\text { P }\end{array}$ & Rendah & SD & IRT \\
\hline 4. & ALP & Tinggi & SMA & Sales \\
\hline 5. & DSYS & Tinggi & SMP & $\begin{array}{c}\text { Pedagan } \\
\mathrm{g}\end{array}$ \\
\hline 6. & YAS & Tinggi & SMA & $\begin{array}{c}\text { Pelayan } \\
\text { Rumah } \\
\text { Makan }\end{array}$ \\
\hline
\end{tabular}

Berdasarkan data diatas menunjukkan bahwa siswa dengan hasil belajar rendah memiliki orang tua yang latarbelakang pendidikan berbeda dengan siswa hasil belajar tinggi. Hasil penelitian dari Zulfitria dalam Referensi [16] menjelaskan bahwa adanya pengaruh yang cukup signifikan terhadap latar belakang pendidikan orang tua (ibu) terhadap prestasi belajar siswa kelas IV, karena semakin tinggi pendidikan orang tua maka semakin tinggi pula prestasi belajar siswa yang di peroleh. Hasil observasi menunjukkan hal yang sama bahwa siswa dengan orang tua yang berasal dari tingkat pendidikan SD memperoleh hasil belajar rendah. Sedangkan siswa yang memiliki hasil belajar tinggi mempunyai orang tua yang tingkat pendidikan setara SMP dan SMA.

Latar belakang pendidikan memang membawa pengaruh bagi hasil belajar siswa tetapi tidak mempengaruhi peningkatan motivasi belajar siswa. Karena orang tua dengan latar belakang pendidikan SD dengan SMP SMA memiliki andil yang sama dalam mendorong dan mendukung kegiatan belajar siswa untuk mencapai tujuan belajar yang diinginkan

Sedangkan dilihat berdasarkan pekerjaan, orang tua pekerja maupun orang tua sebagai ibu rumah tangga sama-sama mempunyai andil dalam pendidikan yang dibutuhkan oleh siswa yag memperoleh hasil belajar rendah maupun siswa yang memperoleh hasil belajar tinggi. Didukung dengan hasil penelitian dari "Ref. [12]" bahwa faktor yang dominan dalam mempengaruhi siswa mengikuti bimbingan belajar adalah faktor keluarga yaitu sebesar $45.80 \%$. Penelitian di bimbingan belajar Omah Sinau yang dilakukan dengan siswa dengan hasil belajar rendah mengatakan bahwa mengikuti bimbingan belajar karen diminta oleh orang tua.

Begitu juga dengan hasil wawancara dengan orang tua dengan hasil belajar tinggi bahwa mereka juga diminta untuk mengikuti bimbel. Hal ini terbukti bahwa walaupun siswa sudah memiliki keinginan untuk mengikuti bimbel tetapi tetap ada dukungan dan dorongan dari orang tua untuk mewujudkannya.

\section{KESIMPULAN}

Siswa dengan hasil belajar rendah ternyata memiliki minat belajar yang baik. Hal tersebut dipengaruhi oleh faktor internal dimana siswa lebih menyukai belajar di bimbel daripada belajar di rumah. Selain itu faktor eksternal yaitu dorongan dari orang tua mengikuti bimbel, peran tutor, dan teman-teman di bimbel Omah Sinau yang membantu menumbuhkan rasa semangat. Maka motivasi 
belajar siswa termasuk kedalam motivasi instrinsik dan motivasi ekstrinsik.

Siswa yang memperoleh hasil belajar tinggi mempunyai keinginan besar dalam belajar. Hal tersebut disebabakan oleh faktor internal dimana siswa memang memiliki keinginan sendiri untuk mengikuti bimbel dan faktor eksternal yaitu dari dukungan orang tua untuk mengikuti bimbingan belajar, peran tutor, dan teman-teman yang ada di bimbingan belajar. Maka motivasi belajar siswa dengan hasil belajar tinggi termasuk kedalam motivasi instrinsik dan motivasi ekstrinsik.

Perbedaan antara siswa dengan hasil belajar tinggi dan siswa hasil belajar rendah terlihat pada minat yang ada di dalam dirinya untuk mengikuti bimbel. Siswa hasil belajar rendah membutuhkan dorongan dari orang tua untuk menumbuhkan motivasi instrinsik dalam dirinya. Siswa hasil belajar tinggi sudah memiliki motivasi instriksik dalam dirinya sehingga dengan keinginannya dia mengikuti bimbingan belajar.

Berdasarkan kategori pekerjaan orang tua, siswa dengan hasil belajar rendah dan tinggi sama-sama mendapatkan dorongan dan dukungan dari orang tua atau disebut faktor eksternal. Adanya andil orang tua dalam mengikut sertakan siswa mengikuti bimbingan belajar membawa dampak yang baik karena siswa mengalami peningkatan motivasi belajar. Berdasarkan latar belakang pendidikan orang tua. Tidak menjadi halangan siswa dalam meningkatkan motivasi belaajr. Karena orang tua sama-sama ikut andil dalam hal yang ingin dicapai oleh siswa dari pencapaian tujuan belajar.

\section{DAFTAR PUSTAKA}

[1] S. Gideon, "Peran Media Bimbingan Belajar Online• Dalam Pembelajaran Ipa Bagi Siswa Smp Dan Sma Masa Kini: Sebuah Pengantar," J. Din. Pendidik., vol. 11, no. 2, p. 167, 2018, doi: $10.33541 /$ jdp.v11i2.813.

[2] Susanto, Bimbingan dan Konseling di Sekolah Konsep, Teori, dan Aplikasinya. Jakarta: Prenada Media Group, 2018.

[3] Siswanto, Bimbingan Sosial. Semarang: Universitas Negeri Semarang Press, 2013.

[4] E. Khoerunnisa and G. A. Grafiyana, "Motivasi Siswa Mengikuti Bimbingan Belajar," Psisula Pros. Berk. Psikol., vol. 1, no. September, pp. 38-44, 2020, doi: 10.30659/psisula.v1i0.7687.

[5] D. Alwan, Menza Hendri, "Faktor-Faktor Yang Mendorong Siswa MIA SMAN Mengikuti Bimbingan Belajar Luar Sekolah Di
Kecamatan Telanaipura Kota Jambi," Dict. Stat. Methodol., vol. 02, no. 01, 2015, doi: 10.4135/9781412983907.n1534.

[6] Slameto, Belajar \& Faktor-Faktor Yang Mempengaruhi. Jakarta: PT Rineka Cipta, 2013.

[7] J. D. Black, S., \& Allen, "Part 1: Foster Intrinsic Motivation," Ref. Libr., pp. 1-16, 2016.

[8] F. Hilmi, "Analysis of Relationship Between Learning Achievement of Tafsir AlQur'an and Arabic Learning Interest," Int. J. Sci. Technol. Res., vol. 2 (12), pp. 336-337, 2013.

[9] M. Syah, Psikologi Pendidikan. Bandung: Remaja Rosdakarya, 2011.

[10] M. Miles, A. \& Huberman, Analisis Data Kualitatif. Jakarta: UIP, 2010.

[11] I. Darimi, "Diagnosis Kesulitan Belajar Siswa Dalam Pembelajaran Aktif Di Sekolah," J. EDUKASI J. Bimbing. Konseling, vol. 2, no. 1, p. 30, 2016, doi: 10.22373/je.v2i1.689.

[12] P. Eriany, L. Hernawati, and H. Goeritno, "Studi Deskriptif Mengenai Faktor-Faktor yang Mempengaruhi Motivasi Mengikuti Kegiatan Bimbingan Belajar pada Siswa SMP di Semarang," Psikodimensia, vol. 13, no. 1, pp. 115-130, 2013.

[13] D. D. A. N. Muhajis, "Analisis hubungan antara motivasi belajar dengan hasil belajar siswa pada sekolah dasar negeri 3 allakuang kecamatan maritengngae kabupaten sidenreng rappang," vol. II, no. 2, pp. 216-228, 2018.

[14] Aritonang. Keke T., "Minat dan Motivasi dalam Meningkatkan Hasil Belajar Siswa," Teach. Coll. Rec., vol. 115, no. 10, pp. 11-21, 2008.

[15] E. Warti, "Pengaruh Motivasi Belajar Siswa terhadap Hasil Belajar Matematika Siswa di SD Angkasa 10 Halim Perdana Kusuma," Mosharafa J. PendidikanMatematika, vol. 5(2), pp. 177-185, 2016.

[16] Zulfitria, "Pengaruh latar belakang pendidikan orang tua terhadap prestasi belajar siswa sd," Holistika, pp. 1-8, 2018, [Online]. Available: https://jurnal.umj.ac.id/index.php/holistika/arti cle/download/2872/2331. 